\title{
Endozoochory of seeds and invertebrates by migratory waterbirds in Oklahoma, USA
}

\author{
Andy J. Green ${ }^{1, *}$, Dagmar Frisch ${ }^{2}$, Thomas C. Michot ${ }^{3}$, Larry K. Allain ${ }^{4}$ and Wylie C. Barrow ${ }^{4}$ \\ ${ }^{1}$ Department of Wetland Ecology, Estación Biológica de Doñana (EBD-CSIC), Avda. Américo Vespucio s/n, \\ 41092 Seville, Spain. \\ ${ }^{2}$ University of Oklahoma Biological Station, HC-71, Box 205, Kingston, OK 73439. \\ ${ }^{3}$ Institute for Coastal Ecology and Engineering, University of Louisiana at Lafayette, USA. \\ ${ }^{4}$ U.S. Geological Survey-National Wetlands Research Center, Lafayette, Louisiana, USA. \\ * Corresponding author: ajgreen@ebd.csic.es
}

Received: 20/9/12

Accepted: 21/1/13

\begin{abstract}
Endozoochory of seeds and invertebrates by migratory waterbirds in Oklahoma, USA

Given their abundance and migratory behavior, waterbirds have major potential for dispersing plants and invertebrates within North America, yet their role as vectors remains poorly understood. We investigated the numbers and types of invertebrates and seeds within freshly collected faecal samples $(n=22)$ of migratory dabbling ducks and shorebirds in November 2008 in two parts of Lake Texoma in southern Oklahoma. Killdeer Charadrius vociferus were transporting a higher number and diversity of both plants and invertebrates than the green-winged teal Anas carolinensis. Ten plant taxa and six invertebrate taxa were identified to at least genus level, although viability was not confirmed for most of these taxa. Bryozoan statoblasts (from four species not previously recorded from Oklahoma) were especially abundant in killdeer faeces, while the ostracod Candona simpsoni was detected as a live adult in torpor in the teal faeces. Cyperaceae and Juncaceae were the most abundant plant families represented and Cyperus strigosus seeds germinated after extraction from killdeer faeces. This snapshot study underlines the importance of waterbirds as vectors of passive dispersal of many organisms and the need for more research in this discipline.
\end{abstract}

Key words: Dispersal ability, Endozoochory, Bryozoa, Plumatella, Charadrius vociferus, Anas carolinensis, Ostracoda, Cyperaceae.

\section{RESUMEN}

Endozoocoria de semillas e invertebrados por aves acuáticas migratorias en Oklahoma, USA

Debido a su abundancia y a sus migraciones, las aves acuáticas tienen un gran potencial como dispersores de plantas e invertebrados en el Norte de América, pero su papel como vectores apenas se ha estudiado. Se investigó la cantidad y diversidad de invertebrados y semillas presentes en heces frescas $(\mathrm{n}=22)$ de patos nadadores y limícolas recogidas en noviembre 2008 en dos zonas del Lago Texoma en el sur de Oklahoma. El chorlitejo colirrojo Charadrius vociferus transportó un número y diversidad de plantas y de invertebrados más alto que la cerceta americana Anas carolinensis. Se identificaron diez taxones de plantas y seis de invertebrados, al menos a nivel de género, aunque para la mayoría de los taxones no se comprobó su viabilidad. Los estatoblastos de briozoos fueron especialmente abundantes en las heces de chorlitejos, mientras que en las heces de una cerceta se recuperó vivo un ejemplar adulto del ostrácodo Candona simpsoni. Las familias Cyperaceae y Juncaceae fueron las más representadas entre las semillas recuperadas, y las semillas de Cyperus strigosus germinaron tras extraerse de las heces. Este breve estudio subraya la importancia de las aves acuáticas como vectores de dispersión para muchos organismos, y la necesidad de más investigaciones en esta línea.

Palabras clave: Capacidad de dispersión, endozoocoria, Bryozoa, Plumatella, Charadrius vociferus, Anas carolinensis, Ostracoda, Cyperaceae. 


\section{INTRODUCTION}

There is a growing appreciation of the role of waterbirds as vectors for dispersal of aquatic plants and invertebrates (Green et al., 2002; Frisch et al., 2007; Brochet et al., 2009; van Leeuwen et al., 2012) and the importance of this process for maintaining connectivity between populations in isolated waterbodies (Amezaga et al., 2002; Figuerola et al., 2005). Passive dispersal via birds is likely to play a vital role in colonization of wetlands in response to habitat creation (e.g. reservoirs, Havel et al., 2005), habitat restoration (McKinstry \& Anderson, 2002; Badosa et al., 2010) or to global change (Brochet et al., 2009). Nevertheless, there remain surprisingly few empirical studies that quantify such dispersal in the field. In North America, there have been recent efforts to study the role of dabbling ducks as vectors of seeds (Holt-Mueller \& van der Valk, 2002; Wongsriphuek et al., 2008, see also Powers et al., 1978). Furthermore, Proctor and coworkers (Proctor, 1964, 1968; Proctor et al., 1967; de Vlaming \& Proctor, 1968) conducted the first detailed investigation of the capacity of waterbirds to disperse seeds and invertebrates that are able to survive passage through the avian gut (endozoochory). Several crustaceans were hatched from faeces recovered from dabbling ducks shot in Texas (Proctor 1964). In Texas, 71 killdeer (Charadrius vociferous) were shot at different times of the year and 27 of them contained intact seeds in the gizzard, mainly of Amaranthus and Polygonum. Experiments with captive birds demonstrated that these seeds can survive gut passage in a viable state (deVlaming \& Proctor 1968).

In this paper we present a snapshot study of endozoochory of plants and invertebrates by dabbling ducks and shorebirds in Oklahoma. Our objectives were to identify as far as possible those taxa present in an apparently viable condition in avian faeces and to compare the potential rates of dispersal recorded in killdeer and the greenwinged teal Anas carolinensis. These bird species were selected on an opportunistic basis.

\section{STUDY AREA AND METHODS}

Lake Texoma is the $12^{\text {th }}$ largest reservoir in the USA by volume and was created by the construction of Denison Dam in the 1940s (Sublette 1955). Fresh samples of faeces were collected from two areas in the Lake Texoma system. On 7 November 2008, six samples were collected from Killdeer along the lakeshore at the Cumberland Pool at Tishomingo National Wildlife Refuge (TNWR, $34^{\circ} 11^{\prime} 19^{\prime \prime} \mathrm{N}, 96^{\circ} 38^{\prime} 53^{\prime \prime} \mathrm{W}$ ). On 11 November, three samples from Killdeer and 11 from green-winged teal were collected from a pond in TNWR $\left(34^{\circ} 11^{\prime} 27^{\prime \prime} \mathrm{N}, 96^{\circ} 38^{\prime} 57^{\prime \prime} \mathrm{W}\right)$ that was adjacent to the lake and only separated from it by a road. In addition, two samples were collected from a mixed flock of A. carolinensis and Mallard A. platyrhynchos on 8-9 November, $37 \mathrm{~km}$ to the south along the shore of Lake Texoma $\left(33^{\circ} 52^{\prime} 39^{\prime \prime} \mathrm{N}, 96^{\circ} 48^{\prime} 27^{\prime \prime} \mathrm{O}\right)$ and adjacent to the University of Oklahoma Biological Station (UOBS). The size of droppings corresponded to those of Mallard.

Duck faeces were collected from spots where flocks (monospecific with the above exception) were observed roosting out of the water. After pinpointing flocks with a telescope, one person remained with the telescope to guide a second person into the correct spot to look for faeces. Killdeer were observed feeding individually and allowed a close approach before flushing, facilitating collection of fresh faeces. Any part of the dropping in contact with soil was removed with a penknife and discarded to avoid contamination. Droppings collected were separated by at least $1 \mathrm{~m}$. Given the numbers of birds present, it is unlikely that any individual bird was sampled more than once. Each dropping was sealed in a plastic tube, then transported immediately to the UOBS for processing.

\section{Extraction of dispersed organisms}

Faecal samples were stored in the dark in a refrigerator at $2{ }^{\circ} \mathrm{C}$ until sieving. Between 9 and 17 November, we washed faeces through stacked $841 \mu \mathrm{m}, 420 \mu \mathrm{m}$ and $62 \mu \mathrm{m}$ sieves using distilled water. Fresh weight for the amount of sieved 
sample was $0.43 \pm 0.043 \mathrm{~g}$ (mean \pm s.e., $n=11)$ for teal, $0.64 \pm 0.13 \mathrm{~g}(n=9)$ for killdeer, 3.47 $\pm 1.30 \mathrm{~g}(n=2)$ for mallard. Items retained on the sieves were placed in sample trays and inspected using a binocular microscope, removing intact invertebrate propagules or plant seeds that were then sorted and placed in tubes with a mineral water. Some invertebrates or eggs were placed in water from Lake Texoma (previously filtered through a $25 \mu \mathrm{m}$ sieve) in Petri dishes at room temperature and any daily development observed.

A representative sample of the seeds extracted were sent for identification to the National Wetlands Research Center (NWRC), where they were stored moist in the refrigerator and compared to images, written descriptions and a seed collection. Seeds of all types that had a total $n>1$ were photographed using a Sony DKC-ST5 camera mounted on a Nikon SM2-2T stereo microscope and sent to Dr. Charles R. Gunn, retired Director of the U.S. National Seed Herbarium, who provided further identifications. Identifications were confirmed at the Seed Herbarium and Arboretum library by Dr. Joseph H. Kirkbride, Jr. of the U. S. National Arboretum. Seed taxa were determined to the most detailed taxonomic classification possible. Photographs of seeds are available on request. In May 2010, seeds were planted in flats of Jiffy Seed Germination Mix and placed in a greenhouse with a maximum daytime temperature of $27^{\circ} \mathrm{C}$ and a minimum night time temp of $23^{\circ} \mathrm{C}$ for three months.

The number of seeds or invertebrates detected per sample and the number of taxa were compared between killdeer and green-winged teal using Mann-Whitney $U$ tests conducted in Statistica 6.0 (StatSoft, Inc. 2000).

\section{RESULTS}

\section{Invertebrates}

Killdeer faeces contained significantly more invertebrates than teal (Mann-Whitney $U$ test, $n=11,9, U=19.5, p=0.02)$ and significantly more invertebrate taxa $(U=21.0, p=0.03)$. The most abundant organisms were the statoblasts of colonial plumatellid bryozoans, which were only found in killdeer (Table 1). Fourteen of the Plumatella statoblasts were identified as follows; four $P$. fungosa, eight $P$. reticulata and two $P$. vaihiriae. In two samples, $P$. reticulata was found to co-occur with either $P$. fungosa or $P$. vaihiriae. Some Plumatella statoblasts were still inside fragments of bryozoan colonies, showing that they had been ingested when birds were feeding on the colonies themselves.

The one ostracod recovered from teal was found to be alive, even though it had been kept in the fridge within the faeces for 6 days before

Table 1. Invertebrate propagules and adults recorded in waterbird faecal samples. Listed are the number of samples with invertebrates (WI), the total number of invertebrates (TI) and the maximum number of in any given sample (Max). Only propagules or adults that were apparently intact are included. Propágulos y adultos de invertebrados registrados en las muestras de heces. Se presenta el número de muestras con invertebrados (WI), el número total de invertebrados (TI) y el número máximo en una sola muestra (Max). Se incluyen solamente los propágulos o adultos aparentemente intactos.

\begin{tabular}{|c|c|c|c|c|c|c|c|c|c|}
\hline \multirow[t]{2}{*}{ Invertebrate type } & \multicolumn{3}{|c|}{ GW Teal $(n=11)$} & \multicolumn{3}{|c|}{ Killdeer $(n=9)$} & \multicolumn{3}{|c|}{ Total $(n=20)$} \\
\hline & WI & TI & Max & WI & $\mathrm{TI}$ & $\operatorname{Max}$ & WI & $\mathrm{TI}$ & $\operatorname{Max}$ \\
\hline Plumatella statoblast & & & & 6 & 42 & 25 & 6 & 42 & 25 \\
\hline Cristatella statoblast & & & & 1 & 1 & 1 & 1 & 1 & 1 \\
\hline Daphnia ephippia & & & & 1 & 1 & 1 & 1 & 1 & 1 \\
\hline Ostracoda $^{1}$ & 1 & 1 & 1 & 1 & 2 & 2 & 2 & 3 & 2 \\
\hline $\begin{array}{l}\text { Other unidentified eggs } \\
\text { (3 Types) }\end{array}$ & 4 & 6 & 2 & 3 & 27 & 20 & 7 & 33 & 20 \\
\hline Total & 4 & 7 & 2 & 8 & 73 & 32 & 12 & 80 & 32 \\
\hline
\end{tabular}

1 adults or subadults. 
extraction. It was first seen moving $5 \mathrm{~h}$ after extraction and was still alive two days later, before fixation in alcohol. This individual was later identified as Candona simpsoni (adult or subadult, probably female, no eggs present).

General faecal contents showed that other food items for teal included aquatic insects such as Coleoptera larvae and gastropods. Killdeer faeces contained aquatic Coleoptera adults and terrestrial insects.

\section{Plant seeds}

Killdeer faeces contained significantly more seeds than teal $(U=4.5, p=0.0001)$ and significantly more plant taxa $(U=7, p=0.0005)$. A total of 166 seeds were recovered from 13 taxa. Overall, $38 \%$ of seeds recovered were Cyperaceae and $43 \%$ Juncaceae (Table 2).

Only three seeds of one type germinated when germination runs were commenced six months after seed extraction. Seedlings were transplanted into 4 " pots and grown until fruiting and identified as Cyperus strigosus. A voucher specimen of this species was placed in the National Wetlands Research Center herbarium.

Strands of filamentous algae in an apparently healthy state (i. e. green with intact cellular struc- ture) were recorded in seven samples from teal and four from killdeer, but were not further identified.

\section{DISCUSSION}

Despite the relatively small sample size, potential endozoochory was demonstrated for six invertebrate taxa and 10 plant taxa that were identified to at least genus level. Given the shortage of similar studies, our results represent a significant advance in the understanding of passive dispersal of plants and invertebrates by migratory waterbirds in North America. However, there is some overlap in the seeds we recorded from killdeer faeces and those recorded by de Vlaming \& Proctor (1968) in killdeer gizzards, which included Eleocharis and Amaranthus. Together with many other seed types, C. strigosus and E. palustris have previously been reported in the gizzards of greenwinged teal in Virginia (Perry, 1981). The dispersal of considerable numbers of Cyperaceae and Juncaceae seeds has been recorded in other field studies of waterfowl faeces (Holt-Mueller \& Van der Valk, 2002; Green et al., 2008; Brochet et al., 2010a) and appears to be a very frequent process.

Although we observed killdeer to transport more seeds and invertebrates than teal, the oppo-

Table 2. Intact seeds recorded in waterbird faecal samples. Shown are the number of samples with intact seeds (WS), total number of seeds (TS) and maximum number in any given sample (Max). Semillas intactas registradas en las muestras de heces. Se presenta el número de muestras con semillas intactas (WS), el número total de semillas (TS) y el número máximo en una sola muestra (Max).

\begin{tabular}{|c|c|c|c|c|c|c|c|c|c|c|c|c|c|}
\hline \multirow[t]{2}{*}{ Plant family } & \multirow[t]{2}{*}{ Taxon } & \multicolumn{3}{|c|}{ Mallard $(n=2)$} & \multicolumn{3}{|c|}{ GW Teal $(n=11)$} & \multicolumn{3}{|c|}{ Killdeer $(n=9)$} & \multicolumn{3}{|c|}{ Total $(n=22)$} \\
\hline & & WS & $\mathrm{TS}$ & Max & WS & TS & Max & WS & $\mathrm{TS}$ & Max & WS & TS & $\operatorname{Max}$ \\
\hline \multirow[t]{3}{*}{ Cyperaceae } & Eleocharis palustris & 1 & 44 & 44 & 1 & 1 & 1 & & & & 2 & 45 & 44 \\
\hline & Cyperus strigosus & & & & & & & 4 & 13 & 5 & 4 & 13 & 5 \\
\hline & Schoenoplectus sp. & & & & & & & 2 & 5 & 4 & 2 & 5 & 4 \\
\hline Juncaceae & Juncus sp. & & & & 3 & 3 & 1 & 6 & 68 & 28 & 9 & 71 & 28 \\
\hline Polygonaceae & Persicaria cf. persicaria & 1 & 4 & 4 & & & & & & & 1 & 4 & 4 \\
\hline Ranunculaceae & Ranunculus sp. & & & & & & & 1 & 1 & 1 & 1 & 1 & 1 \\
\hline Amaranthaceae & Amaranthus sp. & & & & & & & 1 & 1 & 1 & 1 & 1 & 1 \\
\hline Urticaceae & Parietaria cf. pensylvanica & & & & & & & 2 & 7 & 7 & 2 & 7 & 6 \\
\hline Xyridaceae & Xyris sp. & & & & & & & 2 & 2 & 2 & 2 & 2 & 1 \\
\hline Poaceae & Panicum cf. capillare & & & & & & & 1 & 1 & 1 & 1 & 1 & 1 \\
\hline Unidentified (3 Taxa) & & & & & 1 & 3 & 3 & 4 & 13 & 11 & 5 & 16 & 9 \\
\hline Total & & 2 & 48 & 44 & 4 & 7 & 3 & 9 & 111 & 34 & 15 & 166 & 44 \\
\hline
\end{tabular}


site might be found in different locations or dates, owing to the great spatial-temporal variability to be expected in the frequency of dispersal of different taxa by waterbirds (e.g. Figuerola et al., 2003). The closely related Eurasian teal A. crecca is a major seed vector in Europe (Figuerola et al., 2002; Brochet et al., 2009, 2010a) and diet studies in the literature suggest that green-winged teal are often likely to disperse large numbers of seeds and invertebrate propagules such as cladoceran ephippia (Perry, 1981; Johnson, 1995; Frisch et al., 2007).

Teal, mallards and killdeer have an extensive range and make long-distance migratory movements capable of dispersing plants and invertebrates over hundreds of kilometres or more (Johnson, 1995; Jackson et al., 2000; Viana et al., 2012). Teal are only present in the study area during the winter and migration periods, whereas killdeer are resident and likely to be important as vectors of dispersal between waterbodies throughout the annual cycle.

Studies in captivity show the retention times of seeds in the gut of killdeer (Proctor et al., 1967; Proctor, 1968) and the Eurasian teal (Pollux et al., 2005; Brochet et al., 2010b) are sufficient for long-distance dispersal over hundreds of $\mathrm{km}$, when ingestion occurs prior to migratory movements. The same applies to bryozoan statoblasts and other invertebrate propagules (Charalambidou et al., 2003; Sánchez et al., 2012).

The plant taxa dispersed by birds in this study all have broad geographical ranges across North America spanning from Texas to Canada (http://plants.usda.gov/). Darwin (1859) argued that such broad ranges are likely to be largely a consequence of the capacity to disperse via migratory birds. All the Plumatella species recorded are widespread in North America (T. Wood pers. comm.).

We failed to germinate many seeds, perhaps because of the long delay between faeces collection and the commencement of germination runs. Previous studies show that seeds of plants closely related to those recorded here retain high germinability after passage through the gut of dabbling ducks or shorebirds (de Vlaming \& Proctor, 1968; Sánchez et al., 2006; Wongsriphuek et al., 2008; Brochet et al., 2010b; Figuerola et al., 2010).
The relationships between the movement patterns of waterfowl and genetic patterns of Daphnia and Cristatella populations across North America suggest that gene flow mediated by waterfowl is important for these organisms (Figuerola et al., 2005). Owing to the presence of external hooks, it has previously been assumed that $C$. mucedo statoblasts disperse on feathers on the outside of birds (epizoochory). However, the recent observation of large numbers of C. mucedo statoblasts in waterfowl gizzards (Mouronval et al., 2007) and our observation of a statoblast in killdeer faeces suggests that endozoochory may be more important. Recent studies suggest that endozoochory is much more important for seed dispersal by dabbling ducks than epizoochory (Brochet et al., 2010a). However, epizoochory via waterbirds is likely to be important for some seeds and invertebrates (Vivian-Smith \& Stiles, 1994; Figuerola \& Green, 2002; Green \& Figuerola, 2005).

Killdeer appear to be particularly good vectors of propagules found close to the shoreline, both above and below the waterline. These shorebirds do not generally feed at depths of more than a few cm (Jackson et al., 2000) and are likely to have ingested most of the bryozoan statoblasts while feeding on colonies growing on stones or shoreline vegetation. Bryozoans are little known organisms likely to have been overlooked in many studies of waterbird diet, but are also consumed by dabbling ducks (Taylor, 1978). Although this is the first study to confirm the endozoochory of statoblasts in North America, the presence and viability of Plumatella statoblasts in waterfowl faeces has previously been documented in Europe and Australia (Figuerola et al., 2004; Green et al., 2008; Brochet et al., 2010c) and seems likely to be a cosmopolitan process. Because little attention has been paid to freshwater bryozoans, the four species we recorded have not previously been recorded from Oklahoma ( $\mathrm{T}$. Wood pers. comm.).

The transport of torpid ostracod adults or subadults by the closely related Eurasian teal was also recently reported (Frisch et al., 2007) and such transport by waterfowl seems likely to be widespread. Proctor (1964) found a green- 
winged teal shot in Texas to be transporting viable eggs of Cypridopsis vidua and although the endozoochory of ostracod eggs also appears to be a frequent process (Green et al., 2008; Brochet et al., 2010c), the transport of live adults has additional consequences previously overlooked in the literature. In a manner analogous to the endozoochory of insects that live inside plant seeds (Hernández, 2011), parasites and commensalists of ostracods can also be dispersed between water bodies within the adult ostracods found in the avian gut. These might include, for example, helminths that parasitize fish but use ostracods as intermediate hosts (Marcogliese, 1995).

Our results illustrate the value of field studies of endozoochory by waterfowl and shorebirds and underline the importance of birds in the metacommunity ecology of aquatic plants and invertebrates (Amezaga et al., 2002). More extensive studies are recommended, to identify those organisms which are readily dispersed and clarify which groups are likely to be dispersal limited. Such information is useful to managers because it would allow predictions of which taxa will colonize new habitats via waterbirds e.g. after wetland restoration and which can move northwards at a sufficient rate to compensate for climate change.

\section{ACKNOWLEDGMENTS}

Timothy Wood at Wright State University kindly identified the Plumatella statoblasts. John Havel at Missouri State University kindly identified ostracods and commented on an earlier version of this manuscript. Tom Pesacreta, University of Louisiana at Lafayette provided essential help to take the images of the seeds. Larry Weider and the University of Oklahoma Biological Station provided travel funds to the first author. Any use of trade, firm, or product names is for descriptive purposes only and does not imply endorsement by the U.S. Government.

\section{REFERENCES}

AMEZAGA, J. M., L.SANTAMARÍA \& A. J.GREEN. 2002. Biotic wetland connectivity-supporting a new approach for wetland policy. Acta Oecologica, 23: 213-222.

BADOSA, A., D. FRISCH, A. ARECHEDERRA, L. SERRANO \& A. J. GREEN. 2010. Recovery of zooplankton diversity in a restored Mediterranean temporary marsh in Doñana National Park (SW Spain). Hydrobiologia, 654: 67-82.

BROCHET, A. L., M. GUILLEMAIN, H. FRITZ, M. GAUTHIER-CLERC \& A. J. GREEN. 2009. The role of migratory ducks in the long-distance dispersal of native plants and the spread of exotic plants in Europe. Ecography, 32: 919-928.

BROCHET, A. L., M. GUILLEMAIN, H. FRITZ, M. GAUTHIER-CLERC \& A. J. GREEN. 2010a. Plant dispersal by teal (Anas crecca) in the Camargue: duck guts are more important than their feet. Freshwater Biology, 55: 1262-1273.

BROCHET, A. L., M. GUILLEMAIN, M. GAUTHIER-CLERC, H. FRITZ \& A. J. GREEN. 2010b. Endozoochory of Mediterranean aquatic plant seeds by teal after a period of desiccation: Determinants of seed survival and influence of retention time on germinability and viability. Aquatic Botany, 93: 99-106.

BROCHET, A. L., M. GAUTHIER-CLERC, M. GUILLEMAIN, H. FRITZ, A. WATERKEYN, A. BALTANAS \& A. J. GREEN. 2010c. Field evidence of dispersal of branchiopods, ostracods and bryozoans by teal (Anas crecca) in the Camargue (southern France). Hydrobiologia, 637: 255-261.

CHARALAMBIDOU, I., L. SANTAMARÍA \& J. FIGUEROLA. 2003. How far can the freshwater bryozoan Cristatella mucedo disperse in duck guts? Archiv Fur Hydrobiologie, 157: 547-554.

DARWIN, C. 1859. On the Origin of Species by Means of Natural Selection. Murray, London.

DE VLAMING, V. \& V. W. PROCTOR. 1968. Dispersal of aquatic organisms: viability of seeds recovered from the droppings of captive killdeer and mallard ducks. American Journal of Botany, 55: 20-26.

FIGUEROLA, J. \& A. J. GREEN. 2002. How frequent is external transport of seeds and invertebrate eggs by waterbirds? A study in Donana, SW Spain. Archiv Fur Hydrobiologie, 155: 557-565.

FIGUEROLA, J., A. J. GREEN \& T. C. MICHOT. 2005. Invertebrate eggs can fly: Evidence of 
waterfowl-mediated gene flow in aquatic invertebrates. American Naturalist, 165: 274-280.

FIGUEROLA, J., I. CHARALAMBIDOU, L. SANTAMARÍA \& A. J. GREEN. 2010. Internal dispersal of seeds by waterfowl: effect of seed size on gut passage time and germination patterns. Naturwissenschaften, 97: 555-565.

FIGUEROLA, J., A. J. GREEN, K. BLACK \& B. OKAMURA. 2004. Influence of gut morphology on passive transport of freshwater bryozoans by waterfowl in Donana (southwestern Spain). Canadian Journal of Zoology, 82: 835-840.

FRISCH, D., A. J. GREEN \& J. FIGUEROLA. 2007. High dispersal capacity of a broad spectrum of aquatic invertebrates via waterbirds. Aquatic Sciences, 69: 568-574.

GREEN, A. J. \& J. FIGUEROLA. 2005. Recent advances in the study of long-distance dispersal of aquatic invertebrates via birds. Diversity and Distributions, 11: 149-156.

GREEN, A. J., J. FIGUEROLA \& M. I. SÁNCHEZ. 2002. Implications of waterbird ecology for the dispersal of aquatic organisms. Acta Oecologica, 23: $177-189$.

GREEN, A. J., K. M. JENKINS, D. BELL, P. J. MORRIS \& R. T. KINGSFORD. 2008. The potential role of waterbirds in dispersing invertebrates and plants in arid Australia. Freshwater Biology, 53: 380-392.

HAVEL, J. E., C. E. LEE \& M. J. VANDER ZANDEN. 2005. Do reservoirs facilitate invasions into landscapes? Bioscience, 55: 518-525.

HERNÁNDEZ, A. 2011. Internal dispersal of seedinhabiting insects by vertebrate frugivores: a review and prospects. Integrative Zoology, 6: 213 221.

HOLT-MUELLER, M. \& A. G. VAN DER VALK. 2002. The potential role of ducks in wetland seed dispersal. Wetlands, 22: 170-178.

JACKSON, B. J. \& J. A. JACKSON. 2000. Killdeer (Charadrius vociferus), The Birds of North America Online (A. Poole, Ed.). Ithaca: Cornell Lab of Ornithology; Retrieved from the Birds of North America Online: http://bna.birds.cornell.edu/bna/ species $/ 517$

JOHNSON, K. 1995. Green-winged Teal (Anas crec$c a$ ), The Birds of North America Online (A. Poole, Ed.). Ithaca: Cornell Lab of Ornithology; Retrieved from the Birds of North America Online: http://bna.birds.cornell.edu/bna/species/193
MARCOGLIESE, D. J. 1995. The role of zooplankton in the transmission of helminth parasites to fish. Reviews in Fish Biology and Fisheries, 5: 336-371.

MCKINSTRY, M. C. \& S. H. ANDERSON 2002. Creating wetlands for waterfowl in Wyoming. Ecological Engineering, 18: 293-304.

MOURONVAL, J. B., M. GUILLEMAIN, A. CANNY \& F. POIRIER. 2007. Diet of non-breeding wildfowl Anatidae and Coot Fulica atra on the Perthois gravel pits, northeast France. Wildfowl, 57: 68-97.

PERRY, M. C. \& F. M. UHLER. 1981. Asiatic Clam (Corbicula manilensis) and Other Foods Used by Waterfowl in the James River, Virginia. Estuaries, 4: 229-233.

POLLUX, B. J. A., L. SANTAMARÍA \& N. J. OUBORG. 2005. Differences in endozoochorous dispersal between aquatic plant species, with reference to plant population persistence in rivers. Freshwater Biology, 50: 232-242.

POWERS, K. D., R. E. NOBLE \& R. H. CHABRECK. 1978. Seed distribution by waterfowl in southwestern Louisiana. Journal of Wildlife Management, 42: 598-605.

PROCTOR, V. W. 1964. Viability of crustacean eggs recovered from ducks. Ecology, 45: 656-658.

PROCTOR, V. W., C. R. MALONE \& V. L. DEVLAMING. 1967. Dispersal of aquatic organisms: viability of disseminules recovered from the intestinal tract of captive Killdeer. Ecology, 48: 672-676.

PROCTOR, V. W. 1968. Long-distance dispersal of seeds by retention in digestive tract of birds. Science, 160: 321-322.

SÁNCHEZ, M. I., A. J. GREEN \& E. M. CASTELLANOS. 2006. Internal transport of seeds by migratory waders in the Odiel marshes, south-west Spain: consequences for long-distance dispersal. Journal of Avian Biology, 37: 201-206.

SÁNCHEZ, M. I., F. HORTAS, J. FIGUEROLA \& A. J. GREEN. 2012. Comparing the potential for dispersal via waterbirds of a native and an invasive brine shrimp. Freshwater Biology, 57: 1896-1903.

SUBLETTE, J. E. 1955. The physico-chemical and biological features of Lake Texoma (Denison Reservoir), Oklahoma and Texas: a preliminary study. The Texas Journal of Science, 7: 164-182.

TAYLOR, T. S. 1978. Spring foods of migrating Blue-winged Teals on seasonally flooded impoundments. Journal of Wildlife Management, 42: 900-903. 
VAN LEEUWEN, C. H. A., G. VAN DER VELDE, B. VAN LITH \& M. KLAASSEN. 2012. Experimental quantification of long distance dispersal potential of aquatic snails in the gut of migratory birds. Plos One, 7(3): e32292. doi:10.1371/journal.pone.0032292

VIANA, D. S., L. SANTAMARÍA, T. C. MICHOT \& J. FIGUEROLA. 2012. Migratory strategies of waterbirds shape the continental-scale dispersal of aquatic organisms. Ecography, 35: 001-009(EV). VIVIAN-SMITH, G. \& E. W. STILES. 1994. Dispersal of salt marsh seeds on the feet and feathers of waterfowl. Wetlands, 14, 316-319.

WONGSRIPHUEK, C., B. D. DUGGER \& A. M. BARTUSZEVIGE. 2008. Dispersal of wetland plant seeds by mallards: Influence of gut passage on recovery, retention, and germination. Wetlands, 28, 290-299. 